\title{
History of Substance in Philosophy
}

\author{
Bassey Samuel Akpan', Charles Clement Odohoedi² \\ ${ }^{1}$ Department of Philosophy, University of Calabar, Calabar, Nigeria \\ ${ }^{2}$ Department of Philosophy, University of Ibadan, Ibadan, Nigeria \\ Email: samuelbassey15@yahoo.com,oddychalo@yahoo.com
}

How to cite this paper: Akpan, B. S., \& Odohoedi, C. C. (2016). History of Substance in Philosophy. Advances in Historical Studies, 5, 254-270.

http://dx.doi.org/10.4236/ahs.2016.55020

Received: September 27, 2016

Accepted: December 27, 2016

Published: December 30, 2016

Copyright (c) 2016 by authors and Scientific Research Publishing Inc. This work is licensed under the Creative Commons Attribution International License (CC BY 4.0).

http://creativecommons.org/licenses/by/4.0/

\begin{abstract}
A lot of words investigated by philosophers get their inception for conventional or extra-philosophical dialect. Yet the idea of substance is basically a philosophical term of art. Its employments in normal dialect tend to derive, often in a twisted way, different from its philosophical usage. Despite this, the idea of substance differs from philosophers, reliant upon the school of thought in which it is been expressed. There is an ordinary concept in play when philosophers discuss "substance", and this is seen in the concept of object, or thing when this is contrasted with properties, attributes or events. There is also a difference in view when in the sense that while the realists would develop a materialistic theory of substance, the idealist would develop a metaphysical theory of substance. The problem surrounding substance spans through the history of philosophy. The queries have often been what is substance of? And can there be substance without its attributes? This paper tends to expose the historical problems surrounding substance. This paper criticizes the thinking which presupposes that there could be a substance without its attributes or substance existing alone. This paper adopts complimentary ontology principles which state that for anything to exist, it must serve as a missing connection to reality. This suggests that everything interconnects to each other and substance cannot exist in isolation.
\end{abstract}

\section{Keywords}

Substance, Attributes, Metaphysics, Complimentary Reflection

\section{Introduction}

In one of its standard detects, the expression "thing" just means singular substance. It may be questioned that "thing" implies entity, and that "thing" has no customary sense in which it implies singular substance. Truly in one of its usage "thing" implies substance. However it is additionally clear that there is a smaller feeling of "thing", by which it is right to say, for instance, that reasonability is not a "thing", but rather a na- 
ture of a "thing". To this it may be answered that what this illustration shows is that in this sense, "thing" implies solid element, and not singular substance. Be that as it may, clearly, there is a significantly smaller usage of "thing", as indicated by which it is right to say, for case, that a chameleon's turning shading, albeit strengthening, is not a "thing", but rather an adjustment in a "thing", and that a surface or gap, albeit cementing, is not a thing, but rather a point of confinement or nonattendance of a thing. There is no conceivable contrasting option to the possibility that in the last cases "thing" implies singular substance. Metaphysics is one of the chief works of Aristotle and the primary real work of the branch of philosophy with similar name. The essential subject is "being qua being", or being seeing that it is being. It inspects what can be attested about anything that exists in light of its presence and not in view of any unique qualities it has (Aristotle, 1956). Aristotle called metaphysics "First Philosophy" and philosophy of substance since it considers the primary causes and standards of reality. In Aristotle words he claimed that

it is plain that nature in the primary and strict sense is the substance of things which have in themselves, as such, a source of movement; for the matter is called nature because it is qualified to receive this, and processes of becoming and growing are called nature because they are movements proceeding from this. And nature in this sense is the source of the movement of natural objects, being present in them somehow, either potentially or actually (Aristotle, 1985).

From what has been said, then, metaphysics is a branch of philosophy that studies the totality of being in its inclination and structure. It is worth noting that the historical backdrop of western philosophy started with the question: what is the primordial substance of things down till today; this is still a recurring question in metaphysics.

\section{What Is Substance?}

The expression "substance" is irregular in that, while it is a phrase that philosophy has given to common dialect, normal use today is no manual for its conventional essentialness. The word is generally utilized now for stuffs like gold, things tangible and of value. The Greek word which is substantia in Latin and substance in English is much more extensive in application (Broackes, 2006). Ousia is a verbal thing from the verb einai, to be, and a more straightforward interpretation would be or maybe (all the more conceptually) substance (Broackes, 2006). Since numerous sorts of thing can be said in various approaches to be beings, or to be the being of something, the term, obviously, is connected generally. Substance can be seen as a thing or rather the foundation of a thing. As indicated in the mild sense, the substances in a given philosophical framework are those things which are the foundational or major elements of reality. In this manner, for an atomist, particles are the substances (Levy, 2005), for they are the fundamental things from which everything is developed. Omoregbe concur on this when he defines substance has a stuff of which a thing is made, the material it is made out of (Omoregbe, 1991: p. 5). Spinoza sees substance as "that which is in itself and conceived 
through itself, that is, the concept of which it ought to be formed" (Broad, 1995: p. B7). Aristotle states that "substance in the most genuine and essential and most distinct feeling of the word is what is neither predicable of subject nor show in a subject, for example, the individual man or steed" (The Encyclopedia of Philosophy: 36). Substance along these lines implies what constitutes the particular way of a thing. In this sense, it is the righteousness of which a thing is, the thing that it is, as unmistakable from different things or from its qualities. In philosophy there are physical substances as well as metaphysical substance. These physical substantial entities are things as a piece of wood, a dog, a man a house, a tree, or a mountain etc. This view are been held by the realist. Naturally, physical substance has the accompanying six essential attributes. Initial, a physical item can exist unperceived, or possibly, does not exist in righteousness of its being perceived. Second, a physical article involves or is in space. Third, a physical item completely is not situated in two spots on the double. Fourth, a physical question perhaps moves. Fifth, if a physical article is noticeable by any stretch of the imagination, then it has sensible components, is freely recognizable, and is detectable by more than one tactile methodology. Sixth parts which form a compound physical article have solidarity in ethicalness of their instantiating a suitable binding together causal connection. Along these lines, a physical article can be made or pulverized by get together or dismantling (with the exception of on account of major particles, which can't be physically partitioned). The idealist sees substance differently, they believe that substance is not something that can be seen, destroyed or stop to exist. In this case substance is something metaphysical, for instance a dog can died and cease to exist, but the real essence of a dog: the dogness of a dog, still survives. Same as to man, a man can cease to exist, but the real essence of a man, the manness of a man still survives. Human being is significant beings of physical sort. Be that as it may, humans also contain metaphysical substance. As we comprehend the idea of a spirit, a spirit is a nonphysical entity. More particularly, a spirit is an unlocated substance which is fit for consciousness. Souls possibly exist; for as Descartes contended, a reasoning thing could judiciously question the presence of a physical world, while staying sure of its own presence. A substance is durable implies that it continues after some time. It perseveres. It might appear, or stop to exist (as in Aristotle), or it might be uncreated or indestructible (as in Plato, Descartes, Spinoza, or Leibniz), yet in any case, it has an augmented presence in time. A substance as "divisible" implies that its presence is not subject to different things. It exists freely, and it can be isolated from different things that exist. A substance as "indistinguishable" implies that it has a character, in which it is an indistinguishable thing from itself, or in which it has a way of life as the individual from a specific kind-the same as it persists after some time or as it is isolated from different things.

\section{Philosophical History of Substance}

The idea of substance shifts with different savants, reliant upon the school of thought to which they have a place. While the realists would build up a materialistic idea of substance, the idealist would build up an otherworldly or abstract idea of substance. For 
the intensive going empiricist, since substance is not something that can be seen or touched, one would expect that it contain an abstract phenomenal, something not destroyable. The history of western philosophy began by asking the question, what the essential substance of thing in the universe? That is, what is the essential foundation of things in which everything in the world is made from? Thales was the first Greek philosopher who offered a reasonable clarification of the universe. To the inquiry: Thales contended that this essential substance is water (Kett, 1942: p. 99). Consequently for Thales, water is the basic solidarity in all things. Anaximander held that the primordial substance, the essential stuff of which everything is made must be a nonpartisan component not the same as every one of the components we know: endless and uncertain. Anaximenes contended that the essential substance of the universe is air Anaximenes contended that the essential substance of the universe is air (Classen, 1977). While for Heraclitus, the essential way of substance (all the truth) is change, for Parmenides, it is permanence (Omoregbe, 1991). Plato dismissed all realist endeavors to clarify what substance of things is made of. As indicated by Plato, the overseeing standards were "Forms" which have material articles (attributes) endeavored to duplicate. The forces of things he calls Forms are not in the physical realm but in the metaphysical realm while the attributes are things we see in our existential world. While assessments and specific things, he alludes to as unimportant shadows, reflections or impersonations of our present world (Carpenter, 2008). Aristotle is of the view that the way we know a thing gives us the significant piece of information about what we really mean by substance (Stumpf \& Fieser, 2003: p. 82). Aristotle said that we discuss substance and its nine categories. In this sense, the expression "categories" allude to the predicates or the mishaps. He shows the different classes:

Each signifies either substance or quantity or qualification or a relative or where or when or being in a position or having or doing or being affected. To give a rough idea, ideas of substance are man, horse; of quantity: four foot, five foot; of qualification; white, grammatical; of a relative: double, half, larger; of where: in the Lyceum, in the market-place; of when: yesterday, last year; of being in a position: is-lying, is-sitting; of having: has-shoes-on, has-armour-on; of doing: cutting, burning; of being-affected: being-cut, being-burnt. (Aristotle, 1963: pp. 1b25-2a4)

In essence of the above, any individual substances are the subjects of properties in the different classifications, and they can pick up and lose such properties while themselves persevering. For example, taking Samuel for instance, we can clarify the nine categories of Aristotle as takes after:

Substance-Samuel

Quantity-Samuel is $10.5 \mathrm{~m}$ tall

Quality-Samuel is very cleaver

Relation-Samuel is much better than Michele in music

Place-Samuel is in a Church

Time-Samuel was here yesterday

State-Samuel is happy 
Action-Samuel is eating

Position-Samuel is lying down

Affection-Samuel is loved

It is the conviction of Aristotle that for a thing to truly exist, it must be a substance and must have attribute(s) or properties. In this way, substance is said to be inherent and predicate of a thing which are extraneous. Aristotle is of the view that we know a thing better when we comprehend what its size, colour or deportment. Aristotle in this manner recognized vital and unplanned properties of things. For instance, to say that a man has big ear is to depict something unplanned, since to be a human individual it is not vital that a man ought to have big ears. In any case, it is crucial to my being that I am mortal. Henceforth, for him, substance was essentially the individual: a "this" which, conversely with universals, is one of a kind to the person. The substance of the individual Aristotle called primary substance. Plato's substance, the universal essence of a thing, Aristotle called secondary substance. So species and class are second substances. G. Patzig distinguishes Aristotle's substance as "that which is both itself a being among others and a principle and cause of being for all the being in other categories, qualities, quantities, relations and so on (Fadahunsi, 2004: p. 45). In the Categories, Aristotle recognizes primary and secondary substances and makes it clear that primary substances are ontologically fundamental: "if the primary substances did not exist it would be impossible for any of the other things to exist" (Gill, 2005: p. 228). By other things Aristotle implies the secondary substances; this refers to the nine categoriesQuantity, Quality, Relation, Place etc. As cases of primary substances Aristotle gives "the individual man" and "the individual stallion" (Gill, 2005: p. 228). Secondary substances incorporate the species and general under which the essential substances fall, for example, man, horse, creature, and so forth (Gill, 2005: p. 228). Despite the fact that he doesn't utilize the expressions universal and particular in Categories, it is evident that Aristotle would consider primary substances particulars and secondary substances as universals. For he lets us know that primary substances are "not said of a subject" (Lewis, 1991), though secondary substance, for example, man "is said of a subject, the individual man" (Lewis, 1991), and this complies with his meaning of "particular" as well as "universal". Aristotle famously contends that every physical object is a compound of matter and form. Aristotle opines that form is predicated of matter. The type of man, for instance, is not predicated (basically) of both Socrates and Callias, what is universally predicated of both Socrates and Callias is the species man. Matter and form are required to represent some sort of progress. In any change, he claims that, there must be three things: 1) something which underlies and holds on through the change (matter); 2) a "privation", which is one of a couple of contrary energies, the other of which is 3) a form procured over the span of the change (Charlton, 1970). According to Michael Wedin in an attempt to defend Aristotle's theory of substance, he claimed that the primary substance in Metaphysics that is good with the philosophy of the Categories. Wedin contends convincingly that in Metaphysics Aristotle builds up an illustrative hypothesis of substance in which is the reason for being of substances in Categories 
(Wedin, 2000). Amid the medieval period Aquinas with other medieval scholars, have utilized the Aristotelian ideas of substance in articulating the religious philosophy of the Eucharist on the transubstantiation of bread and wine into the body and blood of Christ. As indicated by this custom, the event of the bread and wine don't change, yet their substances change from bread and wine to the Body and Blood of Christ. Through the blend of a unique knowledge, St Thomas Aquinas made a commitment to the way of substance. Aquinas demonstrates that nature exists, since this is show to the faculties. In any case, he demonstrates that "in anything there must be something basic, primary and independent to account for the unity of that thing ... that which is the basic and independent source of a thing's unity and the ultimate subject of all predication is substance" (McMall, 1967: p. 767). St. Thomas recognized the creature substance and the creative substance. The creature substance is recognized from God as substance in that each limited substance has its presence as act in connection to which substance is strength, though just God is His substance the same as His presence. God is an unadulterated being, an immaculate Act and all things considered there is no strength in him. Aquinas differently communicates the subject of metaphysics. Formulae include: ens commune, ens qua ens, and ens inquantum ens. Aquinas is on record as depicting the subject of metaphysics as far as its separateness from matter.

However, even though the subject of this science [metaphysics] is being-in-general [ens commune], the whole science is said to concern what is separate from matter both in existence and in thought. For not only are those things called separate in existence and thought that can never exist in matter, like God and the intellectual substances, but also those that can be without matter, such as being-in-general? (Aquinas, 1961: p. 5)

Aquinas thinks metaphysics manages what is separate from matter both in presence and in thought. The importance of this equation is clear from its subdivision. From one viewpoint, the different alludes to what is never a body. The cases are God and the blessed messengers. To put it plainly, this first sense alludes to otherworldly substances. Then again, the different alludes to what can be separated from matter and also in matter. Cases incorporate ens cooperative and substance. A sign of this second sort of separateness is offered by this content:

We say that being and substance are separate from matter and motion not because it is of their nature to be without them, as it is of the nature of ass to be without reason, but because it is not of their nature to be in matter and motion, although sometimes they are in matter and motion as animal abstracts from reason, although some animals are rational (Aquinas, 1963: p. 89).

Subsequently, the separateness of ens is the explanation behind calling the science "metaphysics": It is called metaphysics because it considers being [ens] and its attendant properties; for these objects that go beyond physics are discovered by a process of analysis as the more universal is discovered after the less universal. I utilized the word here "immateriality" to assign the separateness from matter found in ens. Immaterial 
only centers consideration upon the capacity of the idea to be acknowledged separated from matter. Furthermore ens is not just acknowledged in spiritual things. Other than immateriality, the subject of metaphysics is set apart by composition. It is a composite shared trait. At Summa Contra Gentiles II, 54, Aquinas comments:

It is therefore clear that com position of act and potentiality has greater extension than that of form and matter. Thus, matter and form divide natural substance, while potentiality and act divide common being [ens commune]. Accordingly, whatever follows upon potentiality and act, as such, is common to both material and immaterial created substances, as to receive and to be received, to perfect and to be perfected. Yet all that is proper to matter and form, as such, as to be generated and to be corrupted, and the like, are proper to material substances, and in no way belong to immaterial created substances (Aquinas, 1975: p. 185).

The potency-act demonstration structure has a more noteworthy augmentation than the matter-form arrangement. The matter-form organization runs just through material substances. The intensity demonstration piece reaches out to immaterial made substances also. Aquinas distinguishes these components.

there is in [intellectual and immaterial] substances but one composition of act and potentiality, namely, the composition of substance and be [substantia et esse], which by some is said to be of that which is [quod est] and being [esse], or of that which is and that by which a thing is. On other hand, in substances composed of matter and form there is a twofold composition of act and potentiality: the first, of the substance itself which is composed of matter and form; the second, of the substance thus composed, and being; and this composition also can be said to be of that which is and being, or of that which is and that by which a thing is (Aquinas, 1975: p. 157).

The potency-act demonstration arrangement is normal to both material and immaterial things is the substance-being (esse) organization. Substance and being are coherence that in turn include another intelligibity-that of ens commune itself. In this content, the immateriality of ens lies particularly in its substantia segment. Ens is immaterial in light of the fact that substantia can be acknowledged as a matter-form composition or as a form itself subsisting. In either case, notwithstanding, substantia is still made with esse. From the above, Aquinas depicts ens commune as an inmaterial shared trait as well as a composite shared trait. Ens commune is (1) a shared trait ready to be acknowledged separated from matter and additionally inside matter and (2) a shared characteristic made out of two standards, substance and esse. Duns Scotus in his view of substance is, defines it that:

Substance is proper to whatever it is substance of; nothing is contrary to it; it does not inhere; it is the primary being; it is primary with respect to causality, understanding, definition, perfection, predication and time; it is not genus or motion; it cannot be augmented nor diminished; it is prior to the accidents but is perceived 
by means of the accidents (Yablo, 1992: p. 408).

Amid the Modern Period, there developed an extraordinary enthusiasm for the issue of substance. Descartes characterized substance as that which exists requiring nothing else to exist10. Thusly, a substance is what exists all alone. He proposed three sorts of substances: God, mind and matter. Spinoza worked out the ramifications of this definition by Descartes. He presumes that the main substance is God, since it is just God that requires no other being than himself to exist. Whatever name Descartes provides for the three sorts of substances proposed by Descartes, Spinoza contends that they are all the same names for God. Everything is parts of this one reality: matter and mind. According to Spinoza,

God, Nature and substance are three different names for the same reality. It is the totality of reality and it has infinite attributes although we know only two of them.

These are spirit and matter and it is through these two attributes that we know it.

All things are modifications of this substance and are parts of it (Stumpf \& Fieser, 2003: p. 82).

Spinoza denied Descartes "distinction" between mind and matter. Substance, as indicated by Spinoza, is one and unified, however has various "attributes". In any case, "attribute" is "the thing that we consider as constituting the [single] embodiment of substance". We may think about the single embodiment of the one substance as material furthermore, reliably, as mental. Our world, together with everyone in it, is imminent in God: consequently the acclaimed expression deus sive natura ("God, or Nature"). Spinoza, theory endures degeneration into polytheism (Cook, 2003: p. 560). Farabi's discussion of substance can be found mainly in his commentary on Aristotle's Categories. He claimed that the structure of beings has a necessary character derived from the First being, whereby they all have within themselves some fragment of God and are comprehended by God's knowledge of the world (Druart, 1987). All beings below the heavenly bodies are composed of the two elements of matter and form. Matter is the first stuff and the foundation for form. It can exist in an imperfect manner without form and therefore is that whereby substance is in potency. Matter has no opposite or substratum, but itself is the substratum for all changes (Druart, 1987). Form is the active element of being as is marked by the arrangement of heavenly bodies. It is the act of a substance but can endure only in matter. The hierarchy of forms depends upon how distant a body, which is a mixture of elements, is from the sphere of these materials. He also used Aristotle theory of substance to explain his epistemology and political postulations. The intellect as for al-Farabi is an otherworldly substance that is partitioned, extraordinary, and is the proficient motivation of human knowledge (Druart, 1987). The completely realized intellect has every single subjective form and all the information that man can accomplish. It turns into an unadulterated form that has an indistinguishable rank from other intellectual substances in the pecking order of beings, together with the active intellect, it is of the same similar genus. Regarding this, it might mull over not just itself and the beforehand gained forms in insightfulness information, 
however, it might likewise ponder the dynamic mind and other separate otherworldly substances (Druart, 1987). Leibniz comprehended substance in atomic structure. All that he contends is constituted by monads. What's more, monad, he characterizes as a straightforward substance-the littlest joins of which everything is made. They are independent (without connection with different monads) and otherworldly elements and in that capacity, since they constitute everything, then all truths are profound. With Leibniz, philosophy takes an idealistic turn (Russell, 2008).

Leibniz contended that the genuinely straightforward substances are the monads which he alluded to as "the genuine particles of nature" or "the components of things". In opposition to particles which are seen as outer bodies, Leibniz saw monads as strengths or energies which are supernatural focuses. Every monad is independent, without connection with whatever other monad. Each of them is the subject of a few predicates. He keeps up that everything is at last otherworldly since the substances with which they are formed are profound elements. In such manner, Frederick Copleston relates: "Every substance or monad is the guideline and wellspring of its exercises: it is not dormant but rather has an internal inclination to movement and self-improvement. Drive, vitality, action are of the embodiment of substance" (Copleston, 2003: p. 298). For Locke, a substance is that part of an individual thing in which its properties is in here. Samuel Stumpf pointed out that Locke moved closer the subject of substance from the judgment aptitudes viewpoint (Stumpf \& Fieser, 2003: p. 256). Despite the way that Locke looks at the theme of substance from the routine viewpoint, he was not prepared to answer the question with exactness. He yielded that if any one dissects himself concerning his considered faultless substance when all is said and done, he will find he has not considered everything, with the exception of supposition of the fact the he knows not what support such qualities which are making direct impression on us (Stumpf \& Fieser, 2003: p. 256). Locke keeps up that substance constitutes the dissent of fragile learning. This leads him to say that the likelihood of substance is "something we know not what" (Locke, 1824). It is suitable to note here that when Locke discusses substance he doesn't mean anything other than material substance (Omoregbe, 1996: p. 21). Since we can just watch a thing's properties, its substance is mysterious. John Locke's opine beneath

The idea that we have, to which we give the general name substance, being nothing but the supposed, but unknown, support of those qualities we find existing, which we imagine cannot subsist sine re substante, without something to support them, we call that support substantia (Broackes, 2006: p. 135).

While Berkeley rejects Locke's material substance as conflicting with the empiricist position, he proposes an otherworldly sort of substance which is spirits. We think about the presence of our own soul through instinct and that of different spirits by inference (Pappas, 1999: p. 133). This regardless, neither Locke nor Berkeley is predictable with the empiricist guideline. David Hume, an exhaustive going empiricist, prevents the presence from claiming the material and profound substance of Locke and Berkeley, In David Hume's framework, impressions and thoughts are the substances, for the same 
reason. Hume, in the Treatise, our knowledge in substance is the consequence of a mix-up or deception.

When we gradually follow an object in its successive changes, the smooth progress of the thought makes us ascribe an identity to the succession... When we compare its situation after a considerable change the progress of the thought is broken; and consequently we are presented with the idea of diversity: In order to reconcile which contradictions, the imagination is apt to feign something unknown and invisible, which it supposes to continue the same under all these variations; and this unintelligible something it calls a substance, or original and first matter (Hume, 1978: p. 220).

The experiences which gave ascend, through our inclination, to our mixed up conviction (in, for instance, substance or causation) are displayed as what our conviction truly confirms. That is, the exact reason for what Hume regards to be an illusion, is reinterpreted as the reductive record of an object. Causation hence display consistent conjunction, or substance a name for a bundle of properties composed absolutely. John Locke's thinking that substance as "something we know not what" and David Hume idea lead to bundle theory. Bundle theory is the ontological hypothesis about object hood in which a subject comprises just of an accumulation (package) of properties or relations (O'Leary-Hawthorne, 1995: p. 194). As per bundle hypothesis, a protest comprises of its properties and nothing more: in this manner neither can there be a question without properties nor would one be able to try and consider such a protest; for instance, package hypothesis asserts that reasoning of an apple propels one likewise to think about its shading, its shape, the way that it is a sort of natural product, its cells, its taste, or if nothing else one other of its properties (Ehring, 2001). Kant talks about things-in-themselves and things-as-they appear-to-us. Substances are things-in- themselves. Kant contends like Locke in saying that they can't be known. Pretty much as Locke's position on substance is conflicting with his empiricist position, Kant's things-in-themselves is conflicting with his Copernican revolution (Kohl, 2015: p. 95).

Aristotle distinction amongst primary and secondary substance has driven scholars in recent years to discuss Aristotle's 'two frameworks', containing originations of substance (Graham, 1987). In the prior, Categories, substances are just people; in the later work Metaphysics, they are edifices of form and matter. Aristotle, be that as it may, picks the form as more paradigmatically substance. This has confused a few observers. Wiggins for instance, feels that the adjustment in tenet amongst Categories and Metaphysics is completely unhelpful (Wiggins, 1998: p. 232ff). The decision of form as substance causes perplexity on the grounds that the form is by all accounts a general and similar to the secondary substance, thus not the most fundamental instance of substance. Be that as it may, whether considerable structures are universals in Aristotle is a dubious issue. In using an analogy of a Dog named Fido, Irwin differ about whether the doghood that is in Fido is best viewed as the secondary (Universals), or as the specific case of the general doghood (Irwin, 1988). On this view, the most perspicuous method with respect to the individual (primary) substance is not as the composite of shape and 
matter but rather as the form individualized in the matter. The matter is still a vital segment in the substance, however not, as an equivalent figure with the shape, but force for which the form turns into an individual substance. It is clear that in the event in which one holds that Aristotle feels that forms are universals, then forms are not substance, because he had criticized Plato saying forms are not universal (Robinson, 2014). One of Aristotle observers Whitehead's (1931) criticizes Aristotle notion of substance in the lens of Descartes substance. Whitehead's opine that.

The true point of divergence is the false notion suggested by the contrast between the natural meanings of the words 'particular' and 'universal'.... And when we conceive of substance, we merely conceive an existent thing which requires nothing but itself in order to exist. This definition is a true derivative from Aristotle's definition: A primary substance is "neither asserted of a subject nor present in a subject (Whitehead, 1978).

Whitehead also draws ethical significance from this, as Hartshorne claimed. For if each person is self-sufficient to himself and intrinsically independent of all others, have we not a prescription for selfishness and self-centeredness? In Hartshorne words:

All genuine interests and purposes transcend the mere self. Egoism rests on a superstitious absolutizing of self-identity and consequent absolutizing of nonidentity with other persons... Whitehead once humorously summed up the ethical objection to substance theories by remarking, "I sometimes think that all modern immorality is produced by Aristotle's theory of substance." (Hartshorne, 1970: p. 72)

Notwithstanding this obvious inherent separateness of Aristotelian substance, Whitehead was pestered by what he took to be their static nature. He considered Aristotle's "substances" as stolidly, immutably, persisting through time, while obtaining or losing different unplanned qualities. This is the impression he got from Aristotle's Categories. This lead Whitehead to coin the phrase "undifferentiated endurance". Whitehead claim that the impact of Aristotelian subject-predicate rationale, and a rushed misconstrue of what is given during sense encounter is in his words "The baseless metaphysical doctrine of 'undifferentiated endurance' is a subordinate derivative from the misapprehension of the proper character of the extensive scheme" (Leclerc, 1953: p. 225). John Ackrill also pointed out the strain between the two Aristotle originations of matter and its connection to form. On one origination, the connection among form and matter is incidental, while on the other the connection is essential. The essential connection is conspicuous in Aristotle's examinations of the living things (Aristotle, 1956: Z.10, 1035b24-25). A hand isolated from the entire body just bears the name hand, but it can no longer play out its capacity. Furthermore, what is valid for material parts exclusively is valid for the entire body (Nussbaum \& Amelie, 1992: pp. 412b17-25). A human cadaver is not a human body when the soul has evacuated: this is to say that the natural matter is obliterating when accommodating the two thoughts regarding matter, in Aristotle's writings. In the wake of taking a gander at the brief history of Substance from the old time of Philosophy to the current time frame we can see that they have 
been clashing. For this paper will be will characterize the term substances has any given philosophical framework are those things which, as per that framework, are the foundational or central elements of reality.

\section{What Are Attributes}

The expression "attribute", originate from the Latin word "to" and tribuere "ascribe", alludes to what belong to a thing. Subsequently an attribute is what is appropriate to a thing: its vital property. In metaphysics an attribute is what is vital to a spiritual and physical substance, that which communicates the way of a thing, or that without which a thing is unimaginable. Substance can be said to have properties (Thomas, 1999). Substance, be that as it may, has an interminable property or "essence" as some scholars will call it16. In that capacity, an attribute suggests fundamentally a connection to some substance of which it is a viewpoint or a component in its origination. Attributes can likewise be said to inhere in their substance. Descartes opined Attribute has the guideline property which constitutes its tendency and substance, and to which all its different properties are alluded (Kirkebøen, 2001). Spinoza also defines the term "attribute" as, what the intellect perceives of substance as constituting its essence (Kirkebøen, 2001). For instance for Descartes, the attribute of the mind is thinking, doubting. Attributes is also at the very heart of Spinoza's metaphysics. For him they empower us to comprehend and discuss an augmented world and a reasoning world as far as which we comprehend bodies and brains. In their attempt to answer the problem, thinkers have taken after two great inclinations. Some have precluded the objectivity by claiming that attribute can exist independently; others have made it subjective, claiming it is impossible. Aristotle comprehensively recognizes substance and attributes. Aristotle attempted to separate between a substance and its attribute with this in the sentence: "The house is red", the subject of the sentence "the house" alludes to an individual thing, a substance; and the predicate of the sentence "is red" alludes to the attribute of the substance. Along these lines an essential substance as subject is linguistically recognized from its properties as descriptor which "is available in and predicable of a subject". Secondary substances are communicated by all inclusive terms, things, and by its definition; it is not present in a subject but rather is predicable of it.

\section{Substance-Attribute Theory and Its Problem}

Substance-attribute hypothesis is an ontological hypothesis about objecthood, placing that a substance is particular from its attributes. A thing-in-itself is a property-carrier that must be recognized from the properties it bears (attributes) (Lin, 2006: p. 151). Having this as a main priority one could pose fundamental inquiries. What is the relationship amongst substances and attribute? Is it feasible for there to exist one perspective without the other? In the event that "substance" is an element which exists in a manner that it needs no other element so as to exist then of what use is its attributes? These are a portion of the inquiries to address here. Descartes have estimated that it is feasible for a substance to exist with no other thing. Be that as it may, when we pose a 
question of what is real. Are dream object genuine, in the route in which unmistakable substances, for example, seats and trees are? Are numbers genuine? Alternately would it be a good idea for them to be depicted as close to reflections? Is the tallness of a man a reality in the same sense in which he is a reality, or is it only a part of something more concrete, a minor quality that has subsidiary as opposed to significant being and couldn't exist with the exception of as ascribed to something else? This inquiry is some way or another troublesome, however numerous metaphysicians have related thoughts of substance, quality, and connection; they have contended that lone what is significant genuinely exists, albeit each substance has qualities and stands in connection to different substances. Along these lines, a tree is tall and it's decisively 50 yards north of that wall. Troubles start, when illustrations like these are considered important. Expect for the minute that an individual tree what may be known as a solid existent fits the bill for the title of substance; it is only the kind of thing that has qualities and stands in relations. Unless there were substances in this sense, no attributes could be genuine: the tallness of the tree would not exist unless the tree existed. The inquiry can now be raised what the tree would be in the event that it were denied of every one of its qualities and remained in no relations. The idea of a substance in this kind of transcendentalism is that of a thing that exists without anyone else's input, aside from any ascribes it might happen to have; the trouble with this thought is to know how to apply it. Any solid thing one chooses to embody the idea of substance turns out practically speaking to answer a specific portrayal; this implies in actuality that it can't be talked about separated from its attributes. It in this manner, substances are not any more essential creatures than are qualities and relations; without the previous one couldn't have the last mentioned, however similarly without the last one couldn't have the previous. This negate Descartes demonstrate and the bundle theory hypothesis. Ibuanyidanda tries to give a solution to the problem of substance and accident.

Prof Innocent I. Asouzu uses the Igbo philosophy and word Ibuanyidanda (complementarity) as the new ontological skyline around which he elucidates the thought of being (Asouzu, 2007). Inside this skyline, he assigns being as that because of which anything that exist serves a missing connection of reality. The word Ibuanyidanda is a joined word made up of three sections: Ibu which signify "Load or Task"; Anyi significance not difficult for, and Danda, types of ants. This idea Ibuanyidanda draws its motivation from the teachings of conventional Igbo rationalists of the corresponding arrangement of thought. For the customary Igbo "danda" (ants) can surmount the most troublesome difficulties if and just in the event that they work in a symphonious integral brought together manner. Prof. Asouzu posits that "when we say Ibuanyidan$\mathrm{da}$, we are making recourse to such an ontological state of mutual service in complementarity as the horizon of our reflection (Asouzu, 2007). In this way, the possibility of truth in Ibuanyidanda rises above our individual encounters to our aggregate examination. Thus, a thing can be said to be in the event that it has the ability to be gotten a handle inside the structure of shared integral relationship of all existent substances. Asouzu's Ibuanyidanda thought trusts that everything about philosophy needs to man- 
age the mentality or mien with which we grasp reality. In its various methods of doing philosophy, beyond attempting to comprehend and clarify reality looks to inculcate the right sort of attitude or manner in our association with the world. Aristotle perspective of philosophy of essence has attempted to draw a refinement amongst substance and attributes, this has additionally influenced large portions of western philosophers thinking. In Aristotle word as "if these are not substance, there is no substance and no being by any means; for the mishaps of these it can't be on the right track to call beings" (Damböck, 2012: p. 693). This point out what Stegmüller perceives when he opines that in embracing a fanatics stand against metaphysics, positivism likewise had discovered its way on the way of irrationalism, trusting in light of the fact that it trusted that it can get away from the issue postured by transcendentalism (Damböck, 2012). This kind of irrationalism is entirely unavoidable for any theory of essence that gives careful consideration to one and only part of reality. To this Asouzu further places that

Generally, fidelity to Aristotle's metaphysics has resulted in the tendency to see reality as something disjointed, bifurcated and polarised; where what is essential or substantial is easily equated with what is superior, whereas what is accidental is equated with what is inferior and inconsequential (Asouzu, 2011: p. 43).

Asouzu reprimands Aristotle's "theory of substance" as giving in amazing types of, absolutism, which is the piece of philosophical universality, which looks to reject parts of reality from its thought. Other than this clearly most mystical course readings, utilized as a part of instructing for quite a long time, for instance, have subscribed to Aristotle's radical qualification between "embodiment" or "substance" and "mischances". Consequently, they subscribe generally likewise to Aristotle's showing that substance or quintessence does not require mishaps (qualities) to subsist, though mischances need substances on which they inhere. It is fascinating to note, that most disputes in Western rationality, in assorted appearances, spin around the relationship of substance (quintessence) to mishaps. Since a reasoning of quintessence invalidates the characteristic common corresponding reliance between all existent substances, it effectively controls a course of irrationalism. Prof Asouzu opine that "everything that exist serves as a missing connection to reality" (Asouzu, 2007), this infers we ought not see a part of reality more vital than alternate as two or more things exist to serve one another and are not independent. The suggestion for this is that taking a gander at the part of substance and attributes, both essentially go together, there is no requirement for us distinction between this two. On the off chance that we comprehend that we can't know substance without its qualities same as we can't know property without its substance, then we would spare our self from much counter-intuitive philosophical contention.

\section{Conclusion}

This paper has had the ability to reveal the issue of substance and attribute from its root. It starts with the point of what substance and attribute are. These questions are hard to reply in the midst of irregularity and differences from various researchers who 
have opined and estimated on this topic. The possibility of a substance by some metaphysicians is that of a thing that exists without whatever else connected to it, aside from any attributes it might happen to have; the trouble with this recognition is on the utilization of this contention. My position is that any solid thing one chooses to represent the thought of substance turns out practically speaking to answer a specific portrayal; this implies essentially that it can't be discussed separately from its attributes. It in this way rises that substances are not any more essential creatures than are qualities and relations; without the previous one couldn't have the last mentioned, yet similarly without the last one couldn't have the previous. These negate Descartes and the group scholar positions. Ibuanyidanda (complementarily) philosophy has advised us that for anything to exist it must serve as a missing connection of reality. Things can just exist in shared compliment in each other. On account of substance and attributes it is unnecessary in attempting to make a polarity between them, as one can't exist without alternate as Asouzu philosophy calls attention to.

\section{References}

Aquinas, T. (1961). Commentary on the Metaphysics of Aristotle (p. 2). J. P. Rowan (Trans.), Chicago: Henry Regnery Co.

Aquinas, T. (1963). In Meta, Proem. A. Maurer (Trans.), The Division and Methods of the Sciences (p. 89). Toronto: Pontifical Institute of Mediaeval Studies.

Aquinas, T. (1975). Summa Contra Gentiles II (p. 158). J. F. Anderson (Trans.), Notre Dame, Indiana: University of Notre Dame Press.

Aristotle (1956). Metaphysics. H. Tredennick (Trans.), London: Loeb Classical Library.

Aristotle (1963). Categories and De Interpretatione (Clarendon Aristotle Series) (pp. 1b25-2a4). J. Ackrill (Translation and Notes), Oxford: Clarendon Press.

Aristotle (1985). Metaph. V4, 1015 a 13-19 (The Complete Works of Aristotle, The Revised OXford Translation). J. Barnes (Ed.), Princeton.

Asouzu, I. (2007). Ibuanyidanda: New Complementary Ontology. Deutschland: Litverlag Fresnostr.

Asouzu, I. (2011). "Ibuanyidanda" and the Philosophy of Essence 1. Filosofia Theoretica, 1.

Broackes, J. (2006). Substance. Proceedings of the Aristotelian Society, 106, 131-166. https://doi.org/10.1111/j.1467-9264.2006.00191.x

Carpenter, A. D. (2008). Plato on Knowledge and Forms: Selected Essays. Philosophical Review, 117, 138-141. https://doi.org/10.1215/00318108-2007-032

Charlton, W. (1970). Aristotle Physics Books I and II. Translated with Introduction, Commentary, Note on Recent Work, and Revised Bibliography by Charlton, W., Oxford: Clarendon Press.

Classen, C. J. (1977). Anaximander and Anaximenes: The Earliest Greek Theories of Change? Phronesis, 22, 89-102. https://doi.org/10.1163/156852877X00010

Cook, T. (2003). Spinoza: Metaphysical Themes (Review). Journal of the History of Philosophy, 41, 560-561. https://doi.org/10.1353/hph.2003.0054

Copleston, F. (2003). A History of Philosophy (Vol. 4, p. 298). New York: Continuum.

Damböck, C. (2012). Theory Structuralism in a Rigid Framework. Synthese, 187, 693-713. https://doi.org/10.1007/s11229-011-0009-3 
Druart, T. (1987). Substance in Arabic Philosophy: Farabi’s Discussion.

Ehring, D. (2001). Temporal Parts and Bundle Theory. Philosophical Studies, 104, 163-168. http://www.jstor.org/stable/4321155 https://doi.org/10.1023/A:1010327401920

Fadahunsi, A. (2004). Metaphysics. A Historical and Thematic Introduction (p. 45). Ibadan: Hope Publishers.

Gill, M. L. (2005). Aristotle's Metaphysics Reconsidered. Journal of the History of Philosophy, 43, 223-251. https://doi.org/10.1353/hph.2005.0138

Graham, D. W. (1987). Aristotle's Two Systems. Oxford: Clarendon Press.

Hartshorne, C. (1970). Recollections of Famous Philosophers-And Other Important Persons. Southern Journal of Philosophy, 8, 67-82. https://doi.org/10.1111/j.2041-6962.1970.tb02095.x

Hume, D. (1978). A Treatise of Human Nature. P. H. Nidditch (Ed.), Oxford: Clarendon Press.

Irwin, T. (1988). Aristotle's First Principles, Oxford: Clarendon Press.

Kett, W. G. (1942). Thales of Miletus. The Australasian Journal of Optometry, 25, 99-100. https://doi.org/10.1111/j.1444-0938.1942.tb02445.x

Kirkebøen, G. (2001). Descartes’ Embodied Psychology: Descartes' or Damasio's Error? Journal of the History of the Neurosciences, 10, 173-191. https://doi.org/10.1076/jhin.10.2.173.7255

Kohl, M. (2015). Kant on the Inapplicability of the Categories to Things in Themselves. British Journal for the History of Philosophy, 23, 90-114. https://doi.org/10.1080/09608788.2014.978838

Leclerc, I. (1953). Whitehead's Transformation of the Notion of Substance. Philosophical Quarterly, 3, 225-243. https://doi.org/10.2307/2216576

Levy, K. (2005). Is Descartes a Temporal Atomist? British Journal for the History of Philosophy, 13, 627-674. https://doi.org/10.1080/09608780500293026

Lewis, F. A. (1991). Substance and Predication in Aristotle. Cambridge: Cambridge University.

Lin, M. (2006). Substance, Attribute, and Mode in Spinoza. Philosophy Compass, 1, 144-153. https://doi.org/10.1111/j.1747-9991.2006.00015.x

Locke, J. (1824). The Works of John Locke: In Nine Volumes. London: Rivington.

McMall, R. E. (1967). "Substance" in the New Catholic Encyclopedia (Vol. 13). New York: McGraw-Hill Book Company.

Nussbaum, M. \& Amelie, R. (Eds.) (1992). Essays on Aristotle's De Anima. Oxford: Oxford University Press.

O'Leary-Hawthorne, J. (1995). The Bundle Theory of Substance and the Identity of Indiscernibles. Analysis, 55, 191-196. https://doi.org/10.1093/analys/55.3.191

Omoregbe, J. (1991). A Simplified History of Western Philosophy. Ancient and Modern Philos$o p h y$ (p. 5). Lagos: Joja Educational Research and Publications.

Omoregbe, J. (1996). A Simplified History of Philosophy (Vol. 1, p. 21). Lagos: Joja Education Research and Publishers.

Pappas, G. (1999). Berkeley and Scepticism. Philosophy and Phenomenological Research, 59, 133-149. https://doi.org/10.2307/2653461

Robinson, H. (2014) Substance. https://plato.stanford.edu/entries/substance/

Russell, B. (2008). A Critical Exposition of the Philosophy of Leibniz. New York: Cosimo, Inc.

Stumpf, S. E., \& Fieser, J. (2003). Philosophy. History and Problems (6th ed., p. 82). New York: McGraw-Hill Companies. 
The Encyclopedia of Philosophy (Vol. 8, p. 36). New York: Crowell Collier and Macmillan.

Thomas, J. (1999). Intuition and Reality: A Study of the Attributes of Substance in the Absolute Idealism of Spinoza. Avebury Series in Philosophy.

Wedin, M. (2000). Aristotle's Theory of Substance (p. 482). New York: Oxford University Press.

Whitehead, A. (1978). Process and Reality. New York: Free Press.

Whitehead, A. N., \& Griffin, D. R. (1931). Process and Reality. Economica, 251-252.

Wiggins, D. (1998). Substance. In A. C. Grayling (Ed.), Philosophy: A Guide through the Subject (pp. 214-249). Oxford: Oxford University Press.

Yablo, S. (1992). Cause and Essence. Synthese, 93, 403-449. https://doi.org/10.1007/BF01089276

Submit or recommend next manuscript to SCIRP and we will provide best service for you:

Accepting pre-submission inquiries through Email, Facebook, LinkedIn, Twitter, etc. A wide selection of journals (inclusive of 9 subjects, more than 200 journals)

Providing 24-hour high-quality service

User-friendly online submission system

Fair and swift peer-review system

Efficient typesetting and proofreading procedure

Display of the result of downloads and visits, as well as the number of cited articles

Maximum dissemination of your research work

Submit your manuscript at: http://papersubmission.scirp.org/

Or contact ahs@scirp.org 